\title{
Xanthochroina Ganglbauer, 1881, a new genus of Oedemeridae for the Italian fauna (Coleoptera)
}

\author{
Marco A. BOLOGNA ${ }^{1, *}$, Davide BADANO ${ }^{2}$, Riccardo POLONI ${ }^{3}$ \\ ${ }^{1}$ Dipartimento di Scienze, Università Roma Tre - Viale G. Marconi 446, 00146 Roma, Italy - marcoalberto.bologna@uniroma3.it \\ ${ }^{2}$ Dipartimento di Scienze della Terra dell'Ambiente e della Vita, Università degli Studi di Genova - Corso Europa 26, 16132 Genova, \\ Italy; Department of Biology and Biotechnology "Charles Darwin”, Sapienza University of Rome - Piazzale A. Moro 5, 00185 Roma, \\ Italy-davide.badano@gmail.com \\ ${ }^{3}$ Department of Biology, University of Padova - Via Ugo Bassi 58B, 35131 Padova, Italy - riccardo.poloni@gmail.com \\ * Corresponding author
}

\begin{abstract}
In this paper is reported for the first time with certainty the presence in Italy of the genus Xanthochroina, exhibiting a Holarctic discontinuous distribution. The Mediterranean species $X$. auberti is recorded from western Liguria and information on the range of the species is updated.
\end{abstract}

Key words: false blister beetles, Liguria, Mediterranean distribution.

Xanthochroina Ganglbauer, 1881 is a Palaearctic genus of false blister beetles characterized by a remarkably disjunct distribution, only including two species (Vazquez 2002): $X$. auberti (Abeille de Perrin, 1876), with a Mediterranean fragmented range, and $X$. tarsalis (Kôno, 1938), reported for the Ryukyu Islands (Japan) and Taiwan (Švihla 2008). The latter species was originally described as Anancosessinia Kôno, 1938, and later synonymized with Xanthochroina by Mizota (2001). Moreover, the Nearctic species Oxacis bicolor (Leconte, 1851), known from western North America, was also assigned to Xanthochroina by Arnett (1951) and later accepted by Kriska (2002), although convincing evidence of this relationship is still lacking. If the genus placement of O. bicolor is confirmed, the fragmented and relic range of the genus Xanthochroina would represent another rare case of ancient Holarctic disjunct distribution similar to that of the amphibian family Plethodontidae (Bologna \& Balletto 2007).

Xanthochroina auberti (Fig. 1) is associated with Mediterranean open woodlands, especially those characterized by Pinus halepensis Miller, 1786. The larvae of this species are saproxylic, developing on dead wood of Pinus halepensis, while the adults are nocturnal and are attracted to light (phenology July-October) (Vázquez 2002). According to Fadda (2016), this species is occasionally found on flowers and is attracted by aerial wine traps. On the other hand, the hypothetic predaceous habits of adults (see Ponel 1993) are doubtful.

The range of this species appears highly fragmented in the Mediterranean (Švihla 2008): few populations were recorded from isolated localities of Central Morocco (Middle Atlas: Arahou 2008), western Spain (Vasquez \& Lencina 1991; Lencina et al. 2008; Vazquez 2002; Diéguez Fernández 2010) and Baleares (Mallorca: Fleischer 1919 as Asclerostoma reitteri, synonym; Magistretti 1942; Compte 1963; Vazquez 1997, 2002), Southern France and Monaco (e.g. Caillol 1919; Ponel 1993; Allemand 2003; Ponel et al. 2011; Fadda 2016), Croatia (Ganglbauer 1881; Švihla 2008), Hungary (Švihla 2008; Merkl et al. 2010), Greece mainland (Ganglbauer 1881; Brustel \& Kakiopoulos 2009), Southern Anatolia (Vazquez 2002; Kubisz et al. 2007; Švihla 2008), Cyprus (Švihla 2011), NW Iran (Gahari et al. 2017), Lebanon (Ganglbauer 1881; Magistretti 1942), and Israel (Rittner \& Nir 2014).

Xanthochroina auberti was included in the keys to Italian beetles (see Porta 1934) due to its presence in South Eastern France, including the departments of Var and of Alpes Maritimes, biogeographically strictly related to western Liguria. The presence in these departments was confirmed by recent records from Nice, Monaco and other localities close to the Italian border (Lemaire 2011). Magistretti (1967) in his comprehensive paper on the Italian Oedemeridae did not include this species, as well as Angelini et al. (1995), while Švihla $(2008,2011)$ and Gahari et al. (2017) reported $X$. auberti from Italy but not providing any locality, probably based on unpublished data or on the erroneous interpretation of Porta (1934).

We hypothesized the presence of this species in west- 


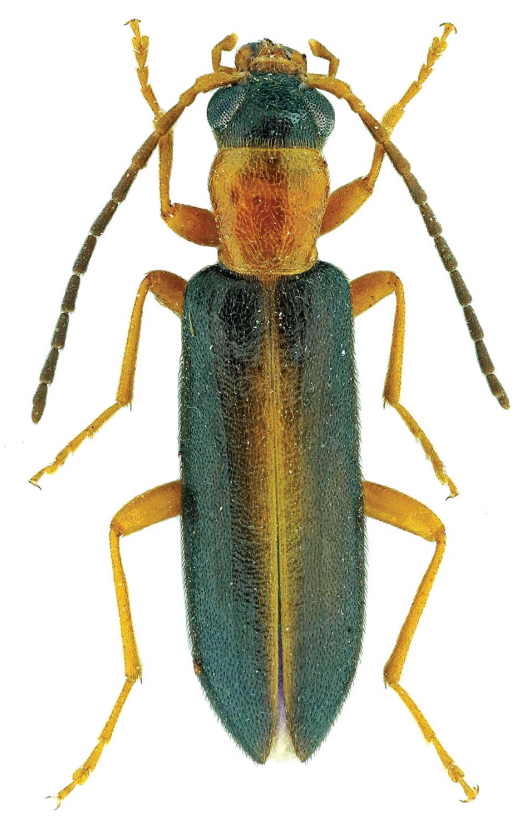

Fig. 1 - Xanthochroina auberti (Abeille de Perrin, 1876), from Greece (Photo: Marco Uliana).

ern Liguria based on the ecological continuity of Mediterranean ecosystems between this region and south eastern France, as also supported by the presence of several Iberian-Provençal species of both plants and animals (e.g. Bo$\operatorname{logna} \&$ Balletto 2007). The presence of the species was actually confirmed by the following record, which represents the first certain locality for the Italian fauna:
Italy: Liguria Region, Imperia province, Bordighera, Monte Nero, 43 47' 35.36" N - $7^{\circ} 41^{\prime} 10.71$ ' E, 20.VIII.2019, UV light trap, D. Badano coll., 4 exx. These specimens, preserved in alcohol 95\%, are housed in the M. A. Bologna collection at the University Roma Tre.

The locality of Monte Nero (Fig. 2) is a Mediterranean scrubland and it is included in the Natura 2000 network (SAC IT1315806 Monte Nero - Monte Bignone), although the area is heavily damaged and often plagued by wildfires. The specimens were collected at light in close proximity of young trees of Pinus halepensis, part of a mixed broadleaves-evergreen stand including short trees and bushes (Pinus, Quercus, Cupressus, Pistacia) bordering a low scrubland with prevalence of Cistus.

Acknowledgements - We are grateful to Dr. Marco Uliana, Museo di Storia naturale di Venezia, who kindly provided the photo of Xanthochroina auberti. Special thanks to Prof. Peter Duelli, Biodiversity and Conservation Biology, Swiss Federal Research Institute WSL, Switzerland, companion of neuropterological field trips, whom equipement was instrumental in this finding.

\section{References}

Abeille de Perrin E. 1876. Diagnose d'une nouvelle espèce française d'Hétéromères. Bulletin des séances de la Société entomologique de France, 67: 179-180.

Allemand R. 2003. Oedemeridae de la faune de France (Coleoptera)/Checklist of the French Oedemeridae (Coleoptera). Publications de la Société Linnéenne de Lyon, 72-73: 229-232. Angelini F., Audisio P., Bologna M.A., De Biase A., Francisco-

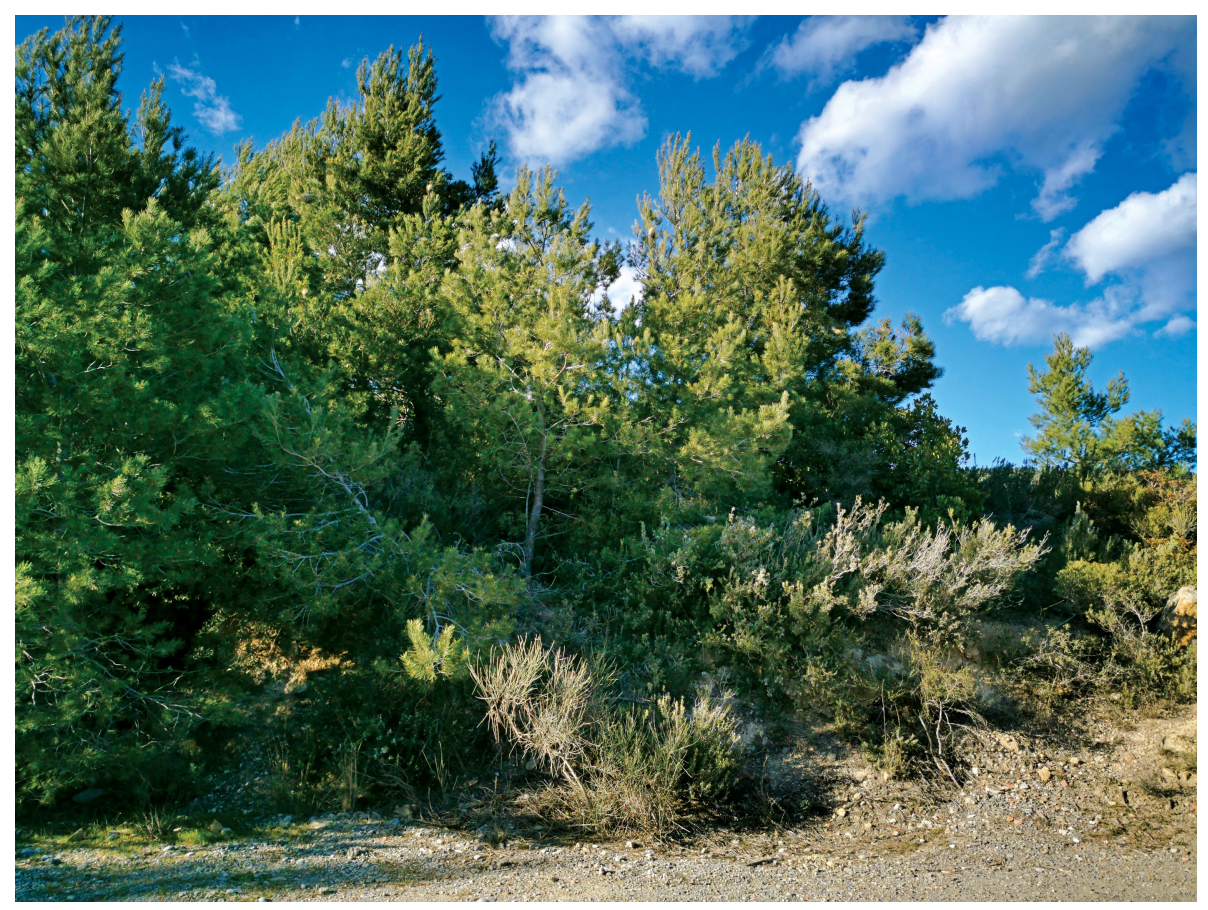

Fig. 2 - Liguria, Bordighera, Monte Nero, the first sampling site in Italy of Xanthochroina auberti (Photo: D. Badano). 
lo M.E., Nardi G., Ratti E. \& Zampetti M.F., 1995. Coleoptera Polyphaga XII (Heteromera escl. Lagriidae, Alleculidae, Tenebrionidae). In: Minelli A., Ruffo S. \& La Posta S. (eds.). Checklist delle specie della fauna italiana, 57, Calderini, Bologna, $30 \mathrm{pp}$.

Arahou M. 2008. Catalogue de l'entomofaune du Chêne vert du Moyen Atlas (Maroc). Documents de l'Institut Scientifique (Rabat), 22: 1-36.

Arnett R.H. jr. 1951. Revision of the Nearctic Oedemeridae (Coleoptera). American Midland Naturalist, 45: 257-391.

Bologna M.A. \& Balletto E. 2007. Biogeografia, pp. 47-56. In: Lanza B., Andreone F., Bologna M. A., Corti C., Razzetti E. (Eds), Amphibia. Fauna d'Italia. XLII. Calderini, Bologna.

Brustel H., Kakiopoulos G. 2009. Contribution a la connaissance de la faune de Grece (Coleoptera: Oedemeridae). Biocosme Mésogéen, Nice, 26: 65-75.

Caillol H. 1919. Catalogue des Coléoptères de Provence, d'après des documents récueillés et groupés. 3ème Partie. Mémoires de la Société Linnéenne de Provence, Marseille, 594 pp.

Diéguez Fernández J.M. 2010. Nuevos coleópteros para Cataluña (NE Península Ibérica) (Insecta: Coleoptera). Arquivos Entomolóxicos, 3: 87-89.

Fadda S. 2016. Les Oedemeridae Latreille, 1810 de la faune de France: clé de détermination et éléments d'écologie et de biologie (Coleoptera Tenebrionoidea). L'Entomologiste, 72: 141-155.

Fleischer A. 1919. Neue paläarktischen Oedemeriden. Entomologischen Blätter, 15: 168-170.

Gahari H., Vázquez X.A., Kubisz D., 2017. Annotated checklist of the false blister beetles (Coleoptera: Tenebrionoidea: Oedemeridae) from Iran. Zootaxa, 4237: 321-334.

Ganglbauer L. 1881. Bestimmungs-Tabellen der Europäischen Coleopteren, IVa. Oedemeridae. Verhandlungen der Zoologisch-Botanischen Gesellschaft, Wien, 20 pp. [pp. 97-116]

Kriska N.L. 2002. 109. Oedemeridae Latreille 1810; in Arnett R.H., Thomas M.C., Skelly P.E. \& Frank J.H. (eds.). American Beetles, 2: 514-519.

Kubisz D., Królik R., Dobosz R., Pettersson R.B. 2007. Oedemeridae (Coleoptera, Tenebrionoidea) in Turkey - preliminary check-list and materials to the distribution. Annals of the Upper Silesian Museum (Entomology) 14-15: 111-130.

Lemaire J.-M. 2011. Quelques Coléoptères (Coleoptera) remarquables du parc de la Colline du Chateau (Nice, Alpes-Maritimes, France). Biocosme Mésogéen, Nice, 28: 57-61.

Lencina J.L., Gallego D., Andújar C. 2008. Nuevos datos de
Oedemeridae Latreille 1810 de la Península Ibérica (Coleoptera). Heteropterus, Revista de Entomología, 8: 95-107.

Magistretti M. 1942. Contributo alla Conoscenza degli Oedemeridae paleartici V. Gli Oedemeridae della Collezione Dodero. Memorie della Società entomologica italiana, 21: 5-20

Magistretti M. 1967. Catalogo degli Oedemeridae italiani (Coleoptera). Memorie della Società entomologica italiana, 46: 181-200.

Merkl O., Németh T., György Z., Podlussány A., Szelenczey B., Vig, K. 2010. Further new beetle species in the Hungarian fauna (Coleoptera). Folia Entomologica Hungarica, 71: 23-29.

Mizota K. 2001. Systematic study of Xanthochroina (Coleoptera, Oedemeridae) with particular reference to its disjunct distributional pattern. Special Publications of the Japan Coleopterological Society, 1: 227-240.

Ponel P. 1993. Coléoptères du Massif des Maures et de la dépression permienne périphérique. Faune de Provence, 14, 5-23.

Ponel P., Fadda S., Lemaire J., Matocq A., Cornet M., Pavon D. 2011. Arthropodes de la Principauté de Monaco. Coléoptères, Hétéroptéres Aperçu sur les Fourmis, les Isopodes et les Pseudoscorpions. Direction de l'Environment, Principauté de Monaco. Available from: http://www.troglorites.fr/MonacoBioDiv2011.htm last accessed.

Porta A., 1934. Fauna Coleopterorum Italica. IV. HeteromeraPhytophaga. Stab. Tip. Piacentino, Piacenza, 415 pp.

Rittner O., Nir A. 2014. First records of Nacerdes melanura (Linnaeus 1758) and Xanthochroina auberti (Abeille de Perrin 1876) (Coleoptera: Oedemeridae) from Israel. Zootaxa, 3838: 397-400.

Švihla V. 2008. New Acts and comments, Oedemeridae \& Family Oedemeridae. In: Löbl I. \& Smetana A. (Eds), Catalogue of Palaearctic Coleoptera. Vol. 5. Apollo Books, Stenstrup, pp. $45,353-369$.

Švihla V. 2011. Supplementary notes on the family Oedemeridae (Coleoptera) as published in the Catalogue of Palaearctic Coleoptera with the new data of distribution. Klapalekiana, 47: 83-88.

Vázquez X.A. 1997. Fauna Iberica, vol. V (Oedemeridae, Pyrochroidae, Pythidae, Mycteridae). Museo Nacional de Ciencias Naturales, CSIC, Madrid, 181 pp.

Vázquez X.A. 2002. European Fauna of Oedemeridae. Argania Editio, Barcelona, 179 pp.

Vasquez X.A., Lencina J.L. 1991. Primera cita iberica del género Xanthochroina Ganglbauer, 1881 (Col., Oedemeridae). Boletin de la Sociedad Española de Entomologia, 15: 338. 